\title{
Pandořina skř́ínka: nároky Polska na náhradu škod způsobených nacistickým Německem v době druhé světové války a související majetkoprávní otázky Část 1
}

\author{
Katarína Kukanová
}

Právnická fakulta, Univerzita Karlova

Kontaktnie-mail:kukanovak@gmail.com

\section{Pandora's Box: Claims of Poland for Compensation of Damage Caused by Nazi Germany during the Second World War and Related Issues of Property Rights}

Part 1

\begin{abstract}
:
The Polish claims for compensation from Germany in connection with damages caused to Poland and its nationals by the Third Reich during the World War II cannot be understood without examining the wider historical, political, and legal context, as well as, the role of the United States of America in the multilateral and bilateral negotiations of the Holocaust victims' compensation that were reopened in the aftermath of the collapse of the communist regimes in Eastern Europe. The series of three articles, that will be subsequently published in Právněhistorické studie, examines the above topic in close liaison to the legal opinions issued by the national assemblies of Poland and Germany in August and September 2017. The first of these articles focuses on the political and legal grounds of the Polish claims in post-war Europe, during communism and in the 1990s. The article argues that Polish claims for compensation from Germany were legally extinguished at the beginning of 1990s, but the further political steps of Germany in relation to the Holocaust victims' compensations created an argumentative space for Poland to reopen the issue on the international level. The second article focuses on the interrelated theme of German and Jewish claims against Poland for compensation in relation to the confiscation of their property in the aftermath of World War II. While the claims of the Expelled Germans were politically and legally closed in 2004, Poland has not yet been able to close the issue of Jewish property restitution in a way that would satisfy the international Jewish organizations as well as the United States of America that have adopted this issue into their diplomatic agenda. The third article analyses the role of the US subjects (Congress, courts, government, media and NGOs) in the negotiations of the Holocaust victims' compensation for sleeping assets in the Swiss banks, forced labour and forced transports organized by the French SNCF, as well as their role in the restitution process in Central and Eastern Europe. The author's view is that the
\end{abstract}


American pressure on the restitution of Jewish property in Poland (including the heirless property) contributed to the decision of the Polish government to reopen the issue of Polish claims for compensation from Germany in 2017.

\section{Key words:}

Poland; international relations; international law; World War II; war reparations; confiscations; restitution

\section{Klíčová slova:}

Polsko; mezinárodní vztahy; mezinárodní právo; druhá světová válka; válečné reparace; konfiskace; restituce

DOI: $10.14712 / 2464689 X .2018 .28$

\section{Úvod}

globalizace světové ekonomiky způsobila, že žádné významné subjekty - banky, společnosti a státy - nejsou imunní vůči tlakům amerických nevládních organizací.“ Ronald W. Zweig ${ }^{1}$

Ve středu 5. července 2017, 22:14 SEČ přistálo na letišti Frederika Chopina devět kilometrů jižně od Varšavy Air Force One. Dveře se otevřely a do tmy zazářila smaragdově zelená. První dáma následovaná svým manželem Donaldem Trumpem právě vstoupila na polské území, aby společně zahájili v pořadí již čtrnáctou prezidentskou návštěvu Spojených států amerických v Polsku. Zatímco Polsko tento okamžik slavilo jako vítězství historickým významem srovnatelné s návštěvou J. F. Kennedyho v Západním Berlíně v roce 1963, západní Evropa nervózně přešlapovala. Politici a média napříč kontinentem sdíleli obavy z prohloubení rozporů v napjatých polsko-německých vztazích. Následující den se prezidenti obou státi potkali na Královském hradě. Poté jejich auta zamírila k památníku Varšavského povstání, kde amerického prezidenta netrpělivě očekával aplaudující dav. V historii americko-polských vztahů to bylo poprvé, co americký prezident nepřišel osobně vzdát poctu židovským obětem nucených transportů u o několik desítek metrů vzdáleného Památníku hrdinů varšavského ghetta, místa, kde před čtyřiceti sedmi lety započala éra německo-polského smíření.

Začátkem následujícího týdne zástupci polské vládnoucí strany Právo a spravedlnost zadali analytickému oddělení polského Sejmu za úkol vypracovat analýzu oprávněnosti polských nároků na náhradu škod způsobených Německem během druhé světové války. ${ }^{2}$ Negativní reakce např́íc Evropou následovala bezprostředně poté, co koncem července Jaroslaw Kaczyński v polském rádiu Marya znovu prohlásil, že Polsko uvažuje o ote-

1 ZWEIG, R. W. German Reparations and the Jewish World: A History of the Claims Conference. 1. vyd. London: Routledge, 2001, s. 7.

2 Právní stanovisko analytického oddělení polského Sejmu v otázce oprávněnosti polských požadavků na odškodnění ze strany Německa v souladu s mezinárodními úmluvami o náhradě škod způsobených v době druhé světové války č. BAS-WAP 1455/17 ze dne 6. záŕí 2017, [online], 6. 11. 2017 [cit. 2017 -11-06]. Dostupné na: http://www.Sejm.gov.pl/media8.nsf/files/KKOI-AR4BNP/\%24File/1455\%20-\%20 17\%20EN.pdf (,Analýza Sejmu, 2017, angl.“). 
vření této otázky. Poté, co stejná slova zazněla z úst členů polské vlády, se k věci vyjádřilo i Německo, a to na tiskové konferenci konané dne 2. srpna 2017: „Samozřejmě, že Německo je politicky, morálně a finančně odpovědné za druhou světovou válku. Doposud vynaložilo a nadále vynakládá vysoké částky na odškodnění válečných škod způsobených nacisty, včetně kompenzací určených Polsku. Nicméně otázka německých reparací Polsku již byla v minulosti vyřešena, a to jak po právní stránce, tak i politicky. "3 Jinými slovy můžeme toto stanovisko německé vlády interpretovat tím způsobem, že zatímco morální odpovědnost Německa za škody způsobené Polsku a jeho státním příslušníkům v době druhé světové války byla Německem uznána a zůstává nezpochybněna, v rovině právní, politické a finanční je tato otázka alespoň z německého pohledu již uzavřena.

Z argumentace německé strany vyplývá, že Polsko se svých nároků v minulosti opakovaně zřeklo. Z komentářù v médiích můžeme nabýt dojem, že vládnoucí strana Právo a spravedlnost otevřením této otázky míří víc dovnitř polské společnosti než navenek vůči zahraničí. V České republice se k intencím Polska vyjádřil například právní historik prof. Jan Kuklík: „... já bych ale viděl, že ta polská iniciativa je do značné míry zaměřena dovnitř polské společnosti... možná se Polsko cítí být posilněno po návštěvě amerického prezidenta Trumpa... je tady samozřejmě vidět konflikt Polska s Evropskou komisí. To může být jeden z těch důvodů. Samožrejmě, je to i určitá strategie polské vlády ve vztahu $\mathrm{k}$ naplnění slibů, které dávala polské veřejnosti před volbami i po volbách. A možná to je pro mě jeden z důvodů, proč jsem použil ten příměr o té Pandořině skř́ince...."4

Ve výčtu těchto důvodů chybí z mého pohledu jeden důležitý. Od pádu komunistického režimu v roce 1989 Polsko čelí dvěma skupinám majetkově právních nároků, které představují pro státní rozpočet Polska značné břemeno. Na straně jedné čelilo Polsko až do roku 2004 německým požadavkům na náhradu škod způsobených odsunem Němců (a konfiskacemi německého majetku) ze západních území, které získalo v důsledku dohod na konferencích v Jaltě a Postupimi. Na straně druhé je na Polsko dlouhodobě vyvíjen silný tlak ve věci restitucí židovského majetku, které Polsko doposud nedořešilo ke spokojenosti židovských organizací a strategických partnerů, zejména Spojených států amerických. Pokud si uvědomíme, že odhadované náklady Polska na restituce židovského i nežidovského soukromého majetku dosahují svojí výší téměř poloviny polského HDP za rok 2016, ${ }^{5}$ pak nás nepřekvapí, že Polsko hledá možnosti, které by celkovou výši této zátěže snížily.

3 Přepis tiskové konference německé spolkové vlády ze dne 2. srpna 2017, [online], 6. 11. 2017 [cit. 2017-11-06]. Dostupné na: https://www.bundesregierung.de/Content/DE/Mitschrift/Pressekonferenzen /2017/08/2017-08-02-regpk.html (,Stanovisko německé vlády, 2017“).

4 Pro a proti: Polské a řecké válečné reparace (21. 9. 2017), Český rozhlas Plus, [online], 6. 11. 2017 [cit. 2017-11-06]. Dostupné na: https://www.youtube.com/watch?v=pq_Ww2mOGsY.

5 Dle informací Kongresu polských Američanů (PAC) se v roce 2016 židovské nároky na odškodnění za soukromý židovský majetek konfiskovaný v době nacistické okupace pohybovaly vưči Polsku ve výši minimálně 50 miliard amerických dolarů, což dle stanoviska PAC tvořilo 20 \% objemu veškerých restitučních nároků vůči Polsku. Ze stanoviska PAC vyplývá, že v př́padě restitucí v objemu požadovaném americkými židovskými organizacemi by Polsko muselo uvolnit celkem 250 miliard amerických dolarů, tj. částku rovnající se zhruba polovině HDP Polska za rok 2016. Dopis PAC adresovaný americké senátorce Barbaře Mikulski dne 17. září 2016, [online], 6. 11. 2017 [cit. 2017-11-06]. Dostupné na: http://www.pac1944.org /presoffice/2016/Let2Mikulski.160917.pdf. 
V následující sérii tř́i článků se budu zabývat tématem oprávněnosti polských nároků na náhradu škod způsobených Německem v době druhé světové války a jeho širším historickoprávním, mezinárodněprávním a mezinárodněpolitickým kontextem.

První článek nazvaný „Polsko a jeho nároky na náhradu škod způsobených Německem v době druhé světové války“ analyzuje širší právně-historický kontext aktuální diskuse o oprávněnosti polských nároků na válečné reparace a náhradu škod způsobených nacistickým Německem v době okupace.

Druhý článek „Odvrácená strana: majetkoprávní nároky fyzických a právnických osob vůči Polsku na náhradu majetku konfiskovaného v souvislosti s druhou světovou válkou a poválečným uspořádáním“ si klade za cíl ozřejmit historickoprávní genezi dvou problematik, které na polské stanovisko ve věci odškodnění společně působí. První problematikou je uznání německo-polské hranice a nároky odsunutých Němců na odškodnění za majetek konfiskovaný na území, které Polsko získalo po druhé světové válce na úkor Německa. Druhou problematikou je téma restitucí židovského majetku v Polsku po roce 1989.

Výše citovaná slova izraelského historika Ronalda W. Zweiga naznačují, že v důsledku globalizace se stal lobbing amerických nevládních organizací významným faktorem, který berou v potaz všechny významné subjekty pohybující se na amerických finančních trzích. Ani Polsko není vůči lobbingu amerických židovských organizací a jejich tlaku na restituce židovského majetku v Polsku imunní. Jednání o odškodnění obětí holokaustu iniciované židovskými organizacemi bezprostředně po rozpadu bipolárního světa naznačují, že podpora Spojených států amerických je pro úspěšnost těchto jednání zásadní. Ve třetím článku, nazvaném „Spojené státy americké a jejich role klíčníka v procesu odškodňování obětí druhé světové války“, poukážu na roli amerických aktérů (kongres, soudy, vláda, média a nevládní organizace) v multilaterálních a bilaterálních jednáních o odškodnění v př́padech židovských spících kont ve švýcarských bankách, nucené práce, nucených transportů organizovaných francouzskou SNCF. Dále v této části nastíním, jakou roli tito aktéři mají v procesu restitucí židovského majetku ve státech střední a východní Evropy. Můj názor, který se ve třetím článku pokusím obhájit, je ten, že americký tlak na restituce židovského majetku v Polsku (včetně majetku obětí bez dědiců, tzv. heirless property) zásadně přispívá k opětovnému otevírání polských požadavků vůči Německu na náhradu škod způsobených druhou světovou válkou.

\section{Část 1: Polsko a jeho nároky na náhradu škod způsobených Německem v době druhé světové války}

Náhrada válečných škod způsobených Německem v době druhé světové války je komplexní problematikou, ve které se prolíná rovina morální, právní a politická. I když se tyto roviny v mnohém překrývají, z prohlášení německé vlády je zřejmé, že odpověd' na otázku oprávněnosti polských nároků se může v jednotlivých rovinách lišit. Zatímco v rovině morálky odpovědnost Německa za válečné škody zpơsobené Polsku a polským státním př́slušníkům nevzbuzuje kontroverze a Německo svoji morální odpovědnost v minulosti opakovaně uznalo a dnes již nezpochybňuje, ${ }^{6}$ v rovině právní a politické se postoje obou států dlouhodobě diametrálně liší.

$6 \quad$ Völkerrechtliche Grundlagen und Grenzen kriegsbedingter Reparationen unter besonderer Berücksichtigung der deutsch-polnischen Situation, WD 2-3000 - 071/17, Bundestag, 2017, [online], 6. 11. 2017 [cit. 
V rovině mezinárodněprávní odpovědnosti je klíčové zejména posouzení právního rámce válečných reparací v Závěrečném protokolu postupimské konference ze dne 2. srpna 1945 a dále právní účinky pozdějších právně relevantních kroků Polska a Německa, které směřovaly k vypořádání se s otázkou odškodnění majetkových křivd souvisejících s druhou světovou válkou a jejími důsledky. Autorčiným názorem je, že v rovině mezinárodního práva veřejného byla otázka polských nároků vůči Německu uzavřena nejpozději ke dni 16. ř́ijna 1991, kdy oba státy uzavřely úmluvu o vytvoření Nadace polsko-německého smíření.

$\mathrm{V}$ rovině mezinárodněpolitické je tato problematika spojena s aspektem politické a ekonomické moci, která v dosavadní praxi jednání o odškodnění obětí holokaustu vždy rozhodla o (ne)úspěšnosti konkrétních iniciativ. Domnívám se, že v rovině mezinárodní politiky se možnosti Polska na dodatečné odškodnění polských státních příslušníků výrazně snížily okamžikem uzavření německo-americké bilaterální úmluvy o vytvoření nadace Připomínka, odpovědnost a budoucnost v roce 2000.

Zde nabízím detailnější pohled na právněhistorický kontext této problematiky:

\section{Válečné škody a jejich identifikace}

Je všeobecně známou skutečností, že v druhé světové válce Polsko utrpělo obrovské populační i materiální ztráty. Ministerstwo Prac Kongresowych (MPK) při polské exilové vládě v Londýně zveřejnilo v únoru 1944 dokument ve věci válečných škod v odpovědnosti Německa, v němž konstatuje: „Ztráty Polska způsobené Německem nelze podřadit pod žádné známé schéma. Jejich důvodem je, že německá okupace, k níž došlo po krátkém období války, je pokračováním války s polským národem. Němci neskrývali, že jejich cílem je zničit polský národ a jeho kulturu za účelem získání nového životního prostoru pro ně samotné. Navíc úkolem okupačních orgánů je zužitkovat zdroje země a práci obyvatelstva pro potřeby války vedené Říší, přičemž do úvahy nejsou vůbec brány zájmy obyvatelstva, které na území žije. Činnost Němců neomezují politické úvahy ani mezinárodní právo. Je zde absolutní volnost vládnutí bez vázanosti pravidly, včetně těch, které sami vydali. Terorizování populace prostřednictvím hromadných zatýkání, transportů do koncentračních táborů a zabíjení, využívání nucené práce, přesunů milionů obyvatel a vyhnání obětí nemá obdoby ani v poslední válce s Německem, ani v jeho aktivitě v jiných okupovaných státech. " 7 Analýza polského Sejmu ze dne 6. záŕí 2017 v této věci uvádí: „, době druhé světové války Polsko utrpělo největší ztráty ze všech evropských států co se týče ztrát populace i národního majetku. Původem těchto ztrát byla nejenom vojenská aktivita, ale zejména okupační politika Německa, zvláště záměrné a organizované vyhlazení populace žijící v okupovaných oblastech Polska a dále intenzivní vykořist'ování polské společnosti, včetně nucené práce a záměrného ničení majetku, mezi jiným taky zboření Varšavy, hlavního města Polska. "8 Tato slova nejen popisují hrůznou politiku nacistického Německa na území Polska, ale také naznačují praktické obtíže, kterým Polsko při identifikaci válečných škod z období druhé světové války čelilo. Záměrné systematické plenění

2017-11-06]. Dostupné na: https:/www.bundestag.de/blob/525616/211fd144be8368672e98ecd6a834fe25 /wd-2-071-17-pdf-data.pdf (,stanovisko německého spolkového sněmu, 2017, něm.“).

7 Dokument č. 1, DĘBSKI, S. - GÓRALSKI, W. M. (eds.). Problem reparacji, odszkodowań i świadczeń w stosunkach polsko-niemieckich 1944-2004. Díl II: Dokumenty. Varšava: PISM, 2004, s. 1 a násl.

$8 \quad$ Analýza Sejmu, 2017, angl., s. 1. 
obrovských rozměrů, k němuž ze strany Německa na území Polska od prvních dnů války docházelo, vedlo k tomu, že identifikace škod byla obtížným úkolem, a to nejen v době války, ale i po jejím skončení. Válečné škody Polska proto nelze zcela přesně vyčíslit ani dnes. ${ }^{9}$ Identifikaci válečných škod navíc stěžovalo to, že objektem systematického plenění se staly i registry a archivy, z nichž mnohé byly v průběhu druhé světové války bud' záměrně zničeny, nebo vyvezeny okupačními armádami do zahraničí, zejména Německa a později Sovětského svazu.

S ohledem na tyto skutečnosti byly informace o škodách způsobených okupační mocí shromažd’ovány polským odbojem prakticky od prvního dne války. Již koncem roku 1939 vznikla na území okupovaného Polska tajná odškodňovací komise, ${ }^{10}$ jejíž členy se stali odborníci z řad polské elity, včetně rektorů vysokoškolských institucí. Jejich úkolem bylo zdokumentovat škody a připravit zprávy pro polskou exilovou vládu v Londýně. Ta na jejich základě informovala západoevropskou veřejnost o situaci v Polsku. ${ }^{11}$ Pro dokumentaci škod v domácím odboji měl zásadní význam vznik Komise pro dokumentaci válečných zločinů, tzv. Niezapominajka, v roce 1944.

Dne 22. července 1944 nová komunistická vláda (PKWN) ve svém manifestu prohlásila, že „Polský výbor národního osvobození určí na systematickém základě výši ztrát, které Německo způsobilo Polsku, a podnikne kroky k zajištění požadavků Polska na odškodnění. "12 Za účelem kalkulace těchto škod byla v září 1944 zřízena Kancelář pro odškodnění válečných ztrát. Na základě rezoluce Rady ministrů ze dne 6. ledna 1945 byla Kancelár připojena $\mathrm{k}$ Prezidiu Rady ministrů. ${ }^{13}$ Hlavním úkolem Kanceláře bylo koordinovat práce na zdokumentování válečných škod, a to jak na úrovni státní správy, tak i na úrovni územní a profesní samosprávy, a dále stanovit jejich celkovou hodnotu pro účely mezinárodních jednání o válečných reparacích. Hlavní práce probíhaly od 21. záŕí 1945 až do 1. ledna 1947, kdy Kancelář vydala závěrečnou zprávu „Sprawozdanie w przedmiocie strat i szkód wojennych Polski w latach 1939-1945“.14 Zpráva se stala podkladem pro polské stanovisko na konferenci zástupců ministrů zahraničních věcí v Londýně v lednu 1947 a později též hlavním pramenem dalších polských stanovisek ve věci válečných reparací a odškodnění

9 GNIAZDOWSKI, M. Damages Inflicted upon Poland by the Germans during the Second World War: an Outline of Research and Estimates. In.: GÓRALSKI, W. M. (eds.). Polish-German Relations and the Effects of the Second World War. Varšava: PISM, 2006, s. 13 a násl.

10 Tamtéž, s. 16.

11 Na základě zpráv z domácího odboje polská exilová vláda koncipovala notu o situaci v Polsku adresovanou spojencům dne 3. května 1941. Tato nota byla později i s př́lohami uveřejněná MZV Polska pod názvem German Occupation in Poland. Extracts of a Note Addressed to the Allied and Neutral Powers. Polish White Book (1942). Ministerstvo informatiky a dokumentace v Londýně dále uveřejnilo knihu The German New Order in Poland (1942), Polské informační centrum v New Yorku uveřejnilo sérii dokumenti̊ Documents Relating to the Administration of Occupied Countries in Eastern Europe (1942). V témže roce vyšla další publikace polské exilové vlády The Mass Extermination of Jews in German Occupied Poland. Note Addressed to the Governments of the United Nations on December 10th, 1942 př́stupná ve formátu Kindle Book na amazon.com. Více informací k pramenům např. GNIAZDOWSKI, c. d., s. 17 a násl.

12 Manifest PKWN ze dne 22. července 1944, [online], 6. 11. 2017 [cit. 2017-11-06]. Dostupné na: https:// upload.wikimedia.org/wikipedia/commons/3/3b/PKWN_Manifest.jpg.

13 RUCHNIEWICZ, K. Polskie zabiegi o odszkodowania niemieckie $w$ latach 1944/45-1975. Wroclaw: Wydawnictwo Uniwersytetu Wrocławskiego, 2007, s. 26 a násl.

14 Sprawozdanie w przedmiocie strat i szkód wojennych Polski w latach 1939-1945, Varšava 1947, [online], 6. 11. 2017 [cit. 2017-11-06]. Dostupné na: http://www.wbc.poznan.pl/dlibra/doccontent?id=68987. 
za škody zpo̊sobené nacistickými okupačními orgány, a to včetně Analýzy Sejmu ze dne 6. záŕí 2017.

Ze zprávy Kanceláře pro odškodnění válečných ztrát vyplývá, že v důsledku druhé světové války zemřelo více než 6 milionů Poláků (6,028 milionu), tj. více než pětina polské předválečné židovské i nežidovské populace. ${ }^{15} \mathrm{Z}$ tohoto údaje 644 tisíc osob zemřelo v důsledku přímých válečných operací a 5,384 milionu osob zemřelo v důsledku persekucí ze strany okupujících orgánů (popravy, oběti koncentračních táborů, epidemie, nucené práce). Tento údaj vyžaduje několik zpřesňujících poznámek. Kvůli obtížím, kterým Kancelář při své práci čelila, byl tento údaj do značné míry výsledkem hrubého odhadu. Za jeho základ byly vzaty výsledky sčítání obyvatelstva v roce $1931,{ }^{16}$ jež bylo provedeno na základě jazykového kritéria. V důsledku použití jazykového kritéria údaj nadhodnocoval počet Poláků na úkor etnických a náboženských menšin. Logicky v něm proto nejsou zohledněny počty etnických a náboženských menšin s výjimkou polských Židů. Z geografického hlediska pak tento údaj vyjadřuje úmrtí, ke kterým došlo nejen na území poválečného Polska, ale též na východních územích. Tato východní území před válkou náležela Polsku, avšak v důsledku dohod na konferencích v Jaltě a Postupimi připadla SSSR. Tato metodika byla odůvodněna úvahou, že polské obyvatelstvo na tomto území by mělo právo opce a mohlo by se tedy po válce z těchto území do Polska přesunout. Z hlediska pozdějších diskusí o polských ztrátách v odpovědnosti Německa je třeba upozornit, že údaj nerozlišuje mezi obětmi německé a ruské okupace, ale vyjadřuje celkový počet polských obětí. Proto je jeho citace v Analýze Sejmu ze dne 6. září 2017 nepřesná.

V pozdějším období byl údaj o populačních ztrátách ve zprávě Kanceláře pro odškodnění válečných ztrát zpochybňován a došlo $\mathrm{k}$ jeho korekci. Z hlediska historických prací zabývajících se dějinami Polska v období druhé světové války je bezesporu zajímavé, že se v otázce údajů o počtu polských obětí v některých případech značně liší, a to v závislosti na období, ve kterém byly napsány. ${ }^{17} \mathrm{~S}$ ohledem na tyto rozdíly byl polským Ústavem

15 Analýza Sejmu, 2017, angl., s. 13; srov. Sprawozdanie w przedmiocie strat i szkód wojennych Polski w latach 1939-1945. c. d., s. 24; v období londýnského exilu MPK odhadlo, že Polsko ztratilo 4114000 obyvatel, z toho 2481000 Židů (bez občanů ztracených ve prospěch Sovětského svazu a polských pracovníků, kteří zmizeli v době bombardování Německa. Za základ populačních ztrát bylo zvoleno produktivní obyvatelstvo (17-59 let), celková škoda byla odhadovaná na 43,355 miliardy polských zlotých, vypočteno na základě průměrné roční mzdy mužů (1 732 polských zlotých) a žen (1 039 polských zlotých); více GNIAZDOWSKI, c. d., s. 18-19.

16 Polský census na základě jazykového kritéria kritizoval např́klad polský sociolog Tadeusz Piotrowski. PIOTROWSKI, T. Poland's Holocaust: Ethnic Strife, Collaboration with Occupying Forces and Genocide in the Second Republic, 1918-1947. Jefferson, North Carolina - London: McFarland \& Company, 1997; Srov. EBERHARDT, P. Ethnic Groups and Population Changes in Twentieth-Century Central-Eastern Europe: History, Data, Analysis Armonk. New York: Routledge, 2003, více např. GNIAZDOWSKI, c. d., s. $20-21$.

17 Například podle odhadů ze 70. a 80. let 20. století se počet polských obětí pohyboval mezi 2,5 až 4 miliony Poláků, nověji historik Piotr Majewski mluví o 1,75 milionu polských obětí německé vyhlazovací politiky vedle dalších 2,7 milionů usmrcených polských Židů, německý historik Dieter Pohl odhaduje celkový počet obětí nacistické politiky na 4,5-5 milionů Poláků, P. K. Piesowicz, C. Luczak a F. Proch mluví o přibližně 6 milionech polských obětí; viz MAJEVSKI, P. Nationalsozialistische Unterdruckungsmassnahmen im Generalgouvernement während der Besatzung. In: MŁYNARCZYK, J. A. (ed.). Polen unter deutscher und sowjetischer Besatzung 1939-1945. Osnabrück: Fibre, 2009; POHL, D. Nationalsozialistische und stalinistische Massenverbrechen: Überlegungen zum wissenschaftlichen Vergleich. In: ZARUSKY, J. (ed.). Stalin und die Deutschen. Neue Beiträge der Forschung (Schriftenreihe des Vierteljahrs hefte für Zeitgeschichte). 
národní paměti uskutečněn robustní výzkum, jehož výsledky byly zveřejněny v roce 2009 . Výsledky výzkumu týmu historiků pod vedením Wojciecha Materski a Tomasze Szarota upřesnily celkový počet polských obětí na 5,62-5,82 milionu, včetně 150 tisíc obětí sovětské okupace. ${ }^{18}$ Podle tohoto výzkumu se celkový počet obětí nacistické okupace pohybuje v rozmezí 5,47-5,67 milionu Poláků, z toho 2,7-2,9 milionu polských Židů. Z výzkumu dále vyplývá, že na populačních ztrátách se podílely tyto příčiny: úmrtí v důsledku př́ímých válečných akti̊ (543 tisíc), úmrtí ve věznicích a táborech (1,146 milionu), vraždy (506 tisíc), smrt mimo věznice a tábory např. v důsledku podvýživy a nemocí (473 tisíc), vraždy ve východní oblasti (100 tisíc), úmrtí v cizině (2 tisíce). ${ }^{19} \mathrm{~V}$ důsledku válečných aktivit a persekucí ze strany okupačních orgánů však újmu na zdraví utrpěl mnohem větší počet Poláků. Analýza polského Sejmu ze dne 6. září 2017 zde odkazuje opět na zprávu Kanceláře pro odškodnění válečných ztrát, která uvádí, že v důsledku války onemocnělo více než 1,14 milionu obyvatel Polska tuberkulózou a 590 tisíc obyvatel se stalo invalidními. ${ }^{20}$

Materiální ztráty byly ze strany polského odboje evidovány prakticky od počátku války. V únoru 1944 MPK odhadovalo polské ztráty na 60 miliard zlotých za první 4 roky války, avšak již v září stejného roku byl tento odhad upřesněn na 100 miliard zlotých. Uvedený odhad nemohl vzít do úvahy tragické události, k nimž došlo na území Polska později, např́iklad zničení Varšavy v důsledku neúspěšného varšavského povstání na podzim 1944. Geograficky se tyto odhady vztahovaly na území předválečného Polska. ${ }^{21}$ Oproti tomu po skončení války bylo nezbytné reflektovat územní změny, k nimž došlo v důsledku jaltské a postupimské konference. Proto se rozsah materiálních škod ve zprávě Kanceláře pro odškodnění válečných ztrát z roku 1947 vztahoval již pouze na území poválečného Polska bez tzv. obnovených území, do nichž patřilo město Gdaňsk a nově získaná německá území na západě země. Celkové materiální škody na tomto území byly ve zprávě vyčísleny na 258432 milionů zlotých a zahrnovaly jak přímé válečné škody v celkové výši 88800 milionů zlotých (zničení vlastního majetku, konfiskovaná produkce v období okupace), tak i neprrímé válečné škody ve výši 169632 milionů zlotých. ${ }^{22} \mathrm{~V}$ přepočtu na americké dolary

München: De Gruyter Oldenbourg, 2006, s. 257; ZARUSKY, J. Timothy Snyder's Bloodlands. A Critical Response to the Construction of a Historical Landscape. In: SCHLEMMER, T. - STEINWEIS, A. E. (ed.). Holocaust and Memory in Europe. Berlin - Boston: Walter de Gruyter GmbH \& Co, 2016, s. 62; PROCH, F. Poland's Way of the Cross. New York: Polish Association of Former Political Prisoners, 1987 s. 143-144; PIESOWICZ, K. Demograficzne skutki II wojny światowej. Studia Demograficzne. 1987, č. $1 / 87$, s. 103-136.

18 Tyto lidské ztráty zahrnují cca 3,5 milionu Poláků, kteří žili na území dnešního Polska, a 2 milionů Poláků, kteří žili na území, které bylo po válce připojeno k Sovětskému svazu; více SZAROTA, T. - MATERSKI, W. (ed.). Polska 1939-1945. Straty osobové i ofiary represji pod dwiema okupacjami. Varšava: IPN, 2009, S. 9.

19 SZAROTA - MATERSKI, c. d., srov. BAJER, K. Zakres udziału Polaków w walce o niepodległość na obszarze państwa polskiego w latach 1939-1945. In: Zeszyty Historyczne Stowarzyszenia Żotnierzy Armii Krajowej. Kraków: Komisja Historyczno-Wydawnicza ZG SŻAK, 1996, s. 14.

20 Analýza Sejmu, 2017, angl., s. 14, srov. Sprawozdanie w przedmiocie strat i szkód wojennych Polski w latach 1939-1945, c. d., s. 22, [online], 6. 11. 2017 [cit. 2017-11-06]. Dostupné na: http://www.wbc .poznan.pl/dlibra/doccontent?id=68987.

21 Dokumenty č. 1 a 2, DĘBSKI - GÓRALSKI, $c . d$.

22 Analýza Sejmu, 2017, angl., s. 13; první odhady v polské exilové vládě v Londýně se uskutečnily na půdě Ministerstwa Prac Kongresowych, které počátkem roku 1944 vyčíslilo polské ztráty na nejméně 60 miliard 
představovala tato částka 48,8 milionu amerických dolarů (na základě kurzu ze srpna 1939, podle kterého se jeden americký dolar rovnal 5,3 polských zlotých).

V pozdějším období se Polsko k nové kalkulaci válečných škod vrátilo ještě několikrát, a to $\mathrm{v}$ návaznosti na diskusi o uzavření mírové smlouvy s Německem a dále v souvislosti s normalizací vztahů se SRN v 70. letech. Zejména v 50. a 60. letech byl nicméně osud těchto iniciativ silně determinován stanoviskem SSSR v této otázce. Otázka kalkulace válečných škod se otevřela znovu v souvislosti s jednáními o polsko-německé smlouvě o normalizaci vztahů mezi SRN a PLR. V prosinci 1970 byla hodnota polských nároků vypočtena na 172,2 milionů USD, což odpovídalo kalkulaci z roku 1947. Analýza Sejmu ze dne 6. září 2017 uvádí, že soukromoprávní nároky fyzických a právnických osob činily z této částky 89,3 milionu USD (v přepočtu 326 milionů německých marek). ${ }^{23} \mathrm{~V}$ důsledku procesu polsko-německého smírení došlo v 70. letech k obnovení historickému výzkumu otázky materiálních škod, avšak zdaleka ne v rozsahu poválečného období. ${ }^{24}$ Nové příležitosti přinesl až vývoj po pádu komunismu.

Specifickou oblastí jsou polské ztráty v oblasti kulturního dědictví. Při jejich identifikaci měla zásadní význam zejména zpráva připravená v londýnském exilu pod vedením prof. Karola Estreichera Cultural losses of Poland. Index of Polish cultural losses during the German occupation, 1939-1944,25 jež se stala jedním z klíčových pramenů identifikace ztracených kulturních hodnot v poválečném Polsku. S ohledem na zvláštní status kulturních statků, který se odráží ve zvláštním právním režimu ochrany a restituce, však není tato problematika předmětem zájmu tohoto článku.

polských zlotých, v zárí téhož roku byl tento odhad upraven na 100 miliard polských zlotých, tyto odhady nezahrnovaly v sobě škodu způsobenou zničením Varšavy ani škodu spojenou s válečnými operacemi v Polsku v letech 1944-1945. GNIAZDOWSKI, c. d., s. 18-19.

23 Analýza Sejmu, 2017, angl., s. 33; srov. RUCHNIEWICZ, K. Polskie zabiegi o odszkodowania niemieckie w latach 1944/45-1975. Vroclav: Wydawnictwo Uniwersytetu Wrocławskiego, 2007, s. 197.

24 V roce 1948 se ministerstvo vnitra rozhodlo pro dodatečnou registraci dalších válečných škod. Proto v letech 1948-1951 byly opět analyzovány podklady zprávy z roku 1947. V souvislosti s diskusí o možnosti uzavření mírové smlouvy došlo k dalšímu znovuoživení myšlenky nové kalkulace materiálních škod na přelomu 50. a 60. let, kdy v roce 1960 vznikla meziministerská komise pro záležitosti týkající se mírové smlouvy s Německem. Její závěry v otázce polských nároků na odškodnění vůči Německu nebyly nikdy publikovány, protože nebyly v souladu s tehdejším sovětským postojem k otázce válečných reparací. V roce 1968 ministerstvo zahraničních věcí vyvinulo iniciativu směrem k otevření otázky válečných reparací na polské straně, což se setkalo s odporem politbyra ústředního výboru sjednocené dělnické strany. Otázka kalkulace válečných ztrát se otevřela znovu v souvislosti s jednáními o polsko-německé smlouvě o normalizaci vztahů mezi SRN a Polskem. Více GNIAZDOWSKI, c. d., s. 22 a nás1.

25 ESTREICHER, Ch. (ed.). Cultural losses of Poland. Index of Polish cultural losses during the German occupation, 1939-1944. Londýn, 1944. Prof. Karol Estreicher (1906-1984) byl v době druhé světové války tajemníkem předsedy polské exilové vlády Władysława Sikorskeho. V rámci této své pozice řídil tým odpovědný za identifikaci kulturních statků, které byly v době války odcizeny z veřejných i soukromých sbírek, později z tohoto týmu vznikla kancelář pro navrácení uloupených kulturních hodnot (Office for the Recovery of Cultural Losses at the Ministry of Congressional Work in London). Kancelář shromažd'ovala informace od polských archivářů, historiků a knihovníků v Polsku a připravovala zprávy. Výše citovaná zpráva po válce sloužila jako podklad činnosti úřadu kompenzace a restituce působící u Ministerstva kultury a pro činnost polských misí usilujících o navrácení kulturních statků vyvážených v době války do Německa a Rakouska. Úřad byl zrušen na počátku padesátých let a obnovil svoji činnost až na začátku 90. let 20. století. V londýnském exilu dále vyšla The Nazi Kultur in Poland (1941) dokumentující polské kulturní ztráty v Polsku, a v New Yorku informační příručka pod názvem German Destruction of Cultural Life in Poland. 


\section{Postupimská dohoda}

Po skončení druhé světové války se mezinárodněprávním základem řešení otázky německých válečných reparací určených Polsku stal Závěrečný protokol postupimské konference ze dne 2. srpna 1945 (Postupimská dohoda). ${ }^{26}$ Pro další osud polských nároků na náhradu škod v odpovědnosti Německa považuji za klíčové tři okruhy problémů souvisejících s Postupimskou dohodou:

(i) vymezení institutu válečných reparací a vztah tohoto institutu $\mathrm{k}$ nárokům fyzických a právnických osob na náhradu škod způsobených v souvislosti s druhou světovou válkou,

(ii) rámcový charakter Postupimské dohody, jež nebyla klasickou mírovou smlouvou, a

(iii) rozdělení válečných reparací mezi východní a západní okupační zónu, v důsledku čehož se Polsko stalo v otázce nároků na válečné reparace závislým na vưli SSSR.

\subsection{Válečné reparace}

$\mathrm{V}$ teorii mezinárodního práva veřejného je vymezení válečných reparací spojeno s definičními obtížemi. Zatímco versailleský režim válečných reparací po první světové válce můžeme považovat za právně propracovaný a jednotný, prohlubující se rozpory mezi SSSR a jeho západními spojenci způsobily, že po druhé světové válce byl režim válečných reparací v dohodách jaltské a postupimské konference formulován vágně a diferencovaně.

V meziválečném období válečné reparace upravovaly předchozí mezinárodněprávní instrumenty, zejména čl. 3 čtvrté Haagské úmluvy o pravidlech zákonů a obyčejů války pozemní (1907) a články 231 a 232 Versailleské mírové smlouvy (1919). Článek 3 čtvrté Haagské úmluvy stanoví, že válečné straně při porušení mezinárodního práva veřejného vzniká povinnost nahradit škodu (compensation), válečná strana přitom odpovídá za veškeré jednání osob, které tvoří součást jejích ozbrojených sil. ${ }^{27}$ Ve shodě s tímto ustanovením článek 231 Versailleské mírové smlouvy stanovil odpovědnost Německa a jeho spojenců za ztráty a škody, které utrpěly vítězné mocnosti, jejich spojenci a jejich státní př́slušníci v důsledku války způsobené německou agresí. ${ }^{28}$ Článek 232 Versailleské mírové smlouvy současně odlišil institut válečných reparací od náhrady škod způsobených civilnímu obyvatelstvu v době agrese, prričemž zavázal Německo k náhradě veškeré škody způsobené civilistům, i kdyby zdroje Německa nestačily k úhradě kompletních válečných reparací. ${ }^{29} \mathrm{Na}$ základě této distinkce část vědy mezinárodního práva veřejného později

26 Zbiór Dokumentów 1946, č. 1, s. 3-33.

27 Convention (IV) respecting the Laws and Customs of War on Land and its annex: Regulations concerning the Laws and Customs of War on Land. The Hague, 18 October 1907.

28 Článek 231 Versailleské mírové smlouvy: „The Allied and Associated Governments affirm and Germany accepts the responsibility of Germany and her allies for causing all the loss and damage to which the Allied and Associated Governments and their nationals have been subjected as a consequence of the war imposed upon them by the aggression of Germany and her allies."

29 Článek 232 Versailleské mírové smlouvy: „The Allied and Associated Governments recognize that the resources of Germany are not adequate, after taking into account permanent diminutions of such resources which will result from other provisions of the present Treaty, to make complete reparation for all such loss and damage. The Allied and Associated Governments, however, require, and Germany undertakes, that she will make compensation for all damage done to the civilian population of the Allied and Associated Powers and to their property during the period of the belligerency of each as an Allied or Associated Power against Germany by such aggression by land, by sea and from the air, and in general all damage as defined in 
rozlišovala mezi institutem válečných reparací, který směřuje k náhradě škod zpo̊sobených státu a jeho státním př́slušníkům $\mathrm{v}$ důsledku válečných aktivit agresora, a mezi institutem náhrady škod vzniklých v souvislosti s válkou v důsledku aplikace vnitrostátního práva okupačními orgány. ${ }^{30}$

Je všeobecně známou skutečností, že versailleský režim válečných reparací ztroskotal, protože neponechával meziválečnému Německu dostatečné finanční zdroje. Stal se konstantním zdrojem napětí v Evropě, přispěl k vítězství nacionálního socialismu a druhé světové válce. Na prahu jaltské a postupimské konference byl proto brán versailleský režim válečných reparací jako negativní precedent. Na jaltské konferenci se vítězné státy dohodly, že po skončení války bude Německo povinné nahradit způsobené škody v co největší míře, avšak neshodly se na jednotném režimu obdobném tomu versailleskému. Naopak rozdělení okupovaného Německa na východní a západní okupační zónu, jež bylo na této konferenci dohodnuto, mělo na režim válečných reparací po druhé světové válec zásadní vliv. ${ }^{31}$

Válečné reparace jsou v Postupimské dohodě upraveny především v hlavě 3 Dohody a dále v hlavě 2B Dohody. V souladu s dohodami na jaltské konferenci založila Postupimská dohoda povinnost Německa „,nahradit v co největší míře škody a utrpení, které způsobilo Spojeným národům a za něž se německý národ nemůže zbavit odpovědnosti“", avšak zvláště v ní bylo zdůrazněno, že ,placení reparací by mělo ponechat německému národu dosti zdrojů, aby mohl žíti bez zahraniční pomoci“.

Z hlediska terminologického lze konstatovat, že na rozdíl od čl. 232 Versailleské mírové smlouvy, Postupimská dohoda nečiní rozdíl mezi válečnými reparacemi a odškodněním s výjimkou př́ilohy 2 Dohody, ve které je termín odškodnění použit v souvislosti s americkým majetkem a investicemi v Německu. Příloha č. 2 Dohody požaduje adekvátní, efektivní a rychlou náhradu (adequate, effective and prompt compensation) těchto škod, jež má mít stejnou prioritu jako reparace. Můžeme proto souhlasit s analýzou polského Sejmu ze dne 6. zář́ 2017, která v této souvislosti konstatuje, že Postupimská dohoda nebránila tomu, aby poškozené státy (včetně Polska) vedle válečných reparací obdržely též jinou finanční kompenzaci ze strany Německa. ${ }^{32}$

Annex I hereto. In accordance with Germany’s pledges, already given, as to complete restoration for Belgium, Germany undertakes, in addition to the compensation for damage elsewhere in this Part provided for, as a consequence of the violation of the Treaty of 1839 , to make reimbursement of all sums which Belgium has borrowed from the Allied and Associated Governments up to November 11, 1918, together with interest at the rate of five per cent $(5 \%)$ per annum on such sums. This amount shall be determined by the Reparation Commission, and the German Government undertakes thereupon forthwith to make a special issue of bearer bonds to an equivalent amount payable in marks gold, on May 1, 1926, or, at the option of the German Government, on the 1st of May in any year up to 1926. Subject to the foregoing, the form of such bonds shall be determined by the Reparation Commission. Such bonds shall be handed over to the Reparation Commission, which has authority to take and acknowledge receipt thereof on behalf of Belgium."

30 Analýza Sejmu, 2017, angl., s. 14-21; srov. RUNDSTEIN, S. Odszkodowania wojenne. In: CYBICHOWSKI, Z. (ed.). Encyklopedia Podręczna Prawa Publicznego (konstytucyjnego, administracyjnego i międzynarodowego). Svazek I. Varšava: Instytut Wydawniczy „Bibljoteka Polska“, 1930, s. 540.

31 Srov. D'ARGENT, P. Reparations after World War II. MPEPIL, 2009.

32 Analýza Sejmu, 2017, angl., s. 18. 


\subsection{Rámcový charakter postupimské dohody a chybějicí mírová smlouva}

Jak již bylo naznačeno výše, do atmosféry a výsledků konference v Postupimi se promítlo výrazné zhoršení vztahů mezi východními a západními spojenci. Tento rozkol způsobil, že se Postupimská dohoda nestala rozhodující mírovou smlouvou, ale pouze součástí př́pravy budoucího mírového uspořádání. Konečné rozhodnutí o řadě otázek bylo proto přenecháno pozdějším dohodám. ${ }^{33} \mathrm{~V}$ důsledku této okolnosti se otázky týkající se důsledků druhé světové války staly předmětem řady parciálních smluv. V západní zóně lze př́kladem zmínit Pařížskou úmluvu o reparacích ze strany Německa, zrrízení Mezispojeneckého reparačního úřadu a o vrácení měnového zlata ze dne 14. ledna 1946, ${ }^{34}$ Bonnskou úmluvu ze dne 26. května 1952, ${ }^{35}$ nebo náhradové dohody, které SRN podepsala s 12 evropskými státy v letech 1959 až $1964 .{ }^{36} \mathrm{~V}$ sovětské zóně můžeme zmínit např́klad polsko-sovětské bilaterální úmluvy ze dne 16. srpna 1945. Můžeme souhlasit se slovy prof. Jana Kuklíka: „celý ten balík problémů... souvisí s tím, že vlastně nebyla uzavřena mírová smlouva

33 Např́iklad KOCOT, K. Problem pojęć: reparacje wojenne, restytucja, odszkodowania itp. w aspekcie umowy poczdamskiej, traktatów pokojowych, umów zawartych przez NRF, wyroków sadowych i doktryny prawa międzynarodowego. Varšava: Ministerstwo Sprawiedliwości. Główna Komisja Badania Zbrodni Hitlerowskich, 1974, s. 65.

34 Polsko v důsledku ustanovení Postupimské dohody nebylo smluvní stranou této úmluvy. Pařížskou úmluvu ze dne 16. ledna 1946 podepsalo 18 států: Spojené státy americké, Austrálie, Belgie, Kanada, Dánsko, Egypt, Francie, Spojené království Velké Británie a Severního Irska, Řecko, Indie, Lucembursko, Norsko, Nový Zéland, Nizozemí, Československo, Jihoafrická republika a Jugoslávie s úmyslem „,to obtain an equitable distribution among themselves of the total assets which, in accordance with the provisions of this Agreement and the provisions agreed upon at Potsdam on 1 August 1945 between the Governments of the United States of America, the United Kingdom of Great Britain and Northern Ireland and the Union of Soviet Socialist Republics, are or may be declared to be available as reparation from Germany (hereinafter referred to as German reparation), in order to establish an Inter-Allied Reparation Agency, and to settle an equitable procedure for the restitution of monetary gold“, [online], 6. 11. 2017 [cit. 2017-11-06]. Dostupné na: http://www.mzv.cz/file/198469/Paris.pdf.

35 Bonnská úmluva mezi Velkou Británií, Francií, Spojenými státy americkými a Spolkovou republikou Německo ze dne 26. května 1952 rozlišovala pojem kompenzace (kapitola 4) a reparace (kapitola 6). Podle kapitoly 4 (kompenzace obětím nacistických persekucí) se SRN zavázala zajistit adekvátní odškodnění (adequate compensation) osobám, které byly persekvovány pro své politické přesvědčení, rasu, víru, nebo ideologii a které v důsledku těchto persekucí utrpěly újmu na životě, zdraví, svobodě, majetku... (s výjimkou individuálně určitelného majetku, který byl předmětem restitucí). Dále osoby pronásledované z důvodu své národnosti, v rozporu s lidskými právy, které byly v době podpisu úmluvy politickými utečenci a dále nepožívají ochranu svého domovského státu, obdrží adekvátní odškodnění (adequate compensation) v případech, kdy jim byla způsobena trvalá újma na jejich zdraví. Kapitola 6 (reparace) stanovila, že otázka reparací bude vyřešena mírovou smlouvou anebo dřívejšími úmluvami týkajícími se reparací.

36 V letech 1959 až 1964 SRN podepsala náhradové dohody se západoevropskými státy podle vzoru Versailleské mírové smlouvy a na ní navazujících smluv: Dánskem (1959, 16 milionů německých marek), Norskem (1959, 60 milionů německých marek), Lucemburskem (1959, 18 milionů německých marek), Francií (1960, 400 milionů německých marek), Belgií (1960, 80 milionů německých marek), Nizozemskem (1960, 125 milionů německých marek), Řeckem (1960, 115 milionů německých marek), Itálií (1961, 40 milionů německých marek), Rakouskem (1961, 101 milionů německých marek), Švýcarskem (1961, 10 milionů německých marek), Velkou Británií (1964, 11 milionů německých marek), Švédskem (1964, 1 milion německých marek); viz Summary of Major Holocaust Compensation Programs In re: Holocaust Victim Assets Litigation (Swiss banks) Special Masters proposal, September 11, 2009, [online], 6. 11. 2017 [cit. 2017-11-06]. Dostupné na: http://www.claimscon.org/forms/allocations/Summary\%20of\%20Major\%20 Holocaust\%20Compensation\%20Programs.pdf. 
s Německem. “37 Obdobně se k neexistenci mírové smlouvy vyjádřil též německý spolkový sněm: „Státy, které se účastnily druhé světové války, nedosáhly v roce 1945 komplexní dohody ohledně závazků německé říše na odškodnění. Nepodmíněná kapitulace německého Wehrmachtu tedy nebyla doprovázena dostatečně odůvodněným uznáním povinnosti platit reparace ze strany německé říše. To mělo být upraveno pouze v rámci konečné mírové dohody. “38 Okolnost, že v důsledku postupného štěpení světa na dva zájmové bloky - východní pod vedením SSSR a západní pod vedením Spojených států amerických - se Postupimská dohoda nestala konečnou mírovou smlouvou, následně vedla k zásadním rozdílům v implementaci jejích ustanovení. Jedním z důsledků byla též výrazně odlišná míra odškodnění východních a západních zemí v bipolárním světě.

Když se ted' vrátíme k terminologické otázce, jak přesně vymezit válečné reparace a jaký je jejich vztah k odškodnění fyzických a právnických osob, vidíme, že v důsledku odlišné implementace Postupimské dohody jsou v sovětském reparačním režimu a v západním reparačním režimu podstatné terminologické rozdíly. Zatímco západní režim válečných reparací rozlišuje mezi institutem válečných reparací a náhradou dalších škod, jež nelze považovat za válečné reparace stricto sensu, východní (sovětský) režim válečných reparací dle čl. 2 hlava 3 Postupimské dohody použivá terminologii válečných reparací a odškodnění jako synonyma, což je kromě jiného důsledek sovětského pojetí vlastnictví a majetkových práv fyzických a právnických osob. Jako příklad lze zmínit ustanovení Bonnské úmluvy mezi Velkou Británií, Francií a Spojenými státy americkými ze dne 26. května 1952 a srovnat je s ustanoveními polsko-sovětské bilaterální úmluvy ze dne 16. srpna 1945 a s prohlášením Rady ministrů Polska z roku 1953. Zatímco Bonnská úmluva výslovně odlišuje institut válečných reparací (kapitola 6) od odškodnění obětí nacistických persekucí (kapitola 4), v prováděcí polsko-sovětské bilaterální úmluvě ze dne 16. srpna 1945 jsou tyto pojmy chápány jako synonyma, přičemž prohlášení Rady ministrů z roku 1953 používá již jenom termín odškodnění. Na této skutečnosti nic nemění ani argumentace polské strany upozorňující na vystoupení polského delegáta na konferenci zástupců ministrů zahraničních věcí v Londýně v lednu 1947, kde polský delegát prohlásil: „V souladu s Postupimskou dohodou, která potvrdila, že Německo bude povinno nahradit v co největší míře škody a utrpení, které způsobilo Spojeným národům - si Polsko vyhrazuje právo vznášet další detailní návrhy v této věci. “39 Polsko na této konferenci např́klad žádalo, aby Německo nahradilo též polské škody v oblasti vědy a kultury a dále restituovalo (anebo nahradilo) veškerý polský majetek, který se nacházel na území Polska (vymezeného hranicemi z Postupimi) a který byl z tohoto území v době války odvezen do Německa. ${ }^{40}$

\section{3 Čl. 2 hlavy 3 Dohody}

Sovětský svaz a Spojené státy americké se na Jaltské konferenci v únoru 1945 dohodly na celkové částce válečných reparací ve výši 20 milionů amerických dolarů (z toho 50 \% pro SSSR) s tím, že reparace mají obdržet v první řadě ty státy, které nesly hlavní břemeno

37 Pro a proti: Polské a řecké válečné reparace (21. 9. 2017) Český rozhlas Plus. [online], 6. 11. 2017 [cit. 2017-11-06]. Dostupné na: https://www.youtube.com/watch?v=pq_Ww2mOGsY.

38 Stanovisko německého spolkového sněmu, 2017, něm., s. 4.

39 Zbiór Dokumentów, 1947, č. 1-2, s. 49.

40 Zbiór Dokumentów, 1947, č. 1-2, s. 45-46. 
války, utrpěly největší ztráty a zajistily vítězství nad nepřítelem. Konference v Postupimi následně rozhodla, že Sovětský svaz a Polsko mají být uspokojeny primárně ze sovětského okupačního pásma $\mathrm{v}$ Německu a dále $\mathrm{z}$ vhodného německého zahraničního majetku náležejícímu k sovětské okupační zóně. Nároky Velké Británie, Francie, Spojených států amerických a ostatních oprávněných států měly být kryty zejména ze západní okupační zóny a vhodným německým zahraničním majetkem náležejícím k této zóně.

Rozdělení válečných reparací mezi východní a západní zónu bylo pro osud polských nároků klíčové. Článek 2 hlavy 3 Postupimské dohody stanovil, že Sovětský svaz uspokojí ze svého reparačního podílu též nároky Polska. Toto ustanovení blíže nespecifikovalo rozsah ani časový harmonogram válečných reparací určených Polsku a ponechávalo řešení na rozhodnutí Sovětského svazu. Z hlediska pozdějšího vývoje se ukázalo být toto ustanovení pro Polsko nevýhodné i proto, že posilovalo jeho ekonomickou a politickou závislost na Sovětském svazu. V tomto kontextu lze zmínit slova J. Kranze: „Byla to dost zvláštní konstrukce a, jak se ukázalo, byla pro Polsko nevýhodná, zejména kvůli feudálně-komunistické povaze polsko-sovětských vztahů po druhé světové válce.“41 V dalším období se právě válečné reparace staly jedním z nástrojů ekonomického vykořist'ování Polska sověty, což se projevilo např́iklad v otázce tzv. reparačního uhlí.

Dne 16. srpna 1945, tj. necelé dva týdny po podepsání Postupimské dohody, se zástupci obou států setkali v Moskvě, kde podepsali provádějící úmluvy k Postupimské dohodě: úmluvu o hranicích mezi Polskem a SSSR ${ }^{42}$ a úmluvu o náhradě škod způsobených nacistickou okupací ${ }^{43} \mathrm{~s}$ dodatkovými protokoly. Zatímco první úmluva určila průběh východní hranice Polska se SSSR, v druhé úmluvě se SSSR vzdalo svých práv k německému majetku na území poválečného Polska, včetně bývalých německých dolů na západním území (jež Polsko získalo v důsledku posunu polsko-německé hranice směrem na západ), a dále přiznalo Polsku 15\% podíl na německých válečných reparacích určených SSSR. Polsko se za to zavázalo dodávat SSSR uhlí v dohodnutém množství za zvýhodněné ceny. Dle této dohody mělo Polsko do SSSR vyvézt 8 milionů tun uhlí v roce 1946, 13 milionů tun uhlí ročně v dalších čtyřech letech a poté 12 milionů tun uhlí ročně až do ukončení okupace Německa. V tajném protokolu ke smlouvě se obě strany dohodly na zvýhodněné ceně 1,25-1,35 USD za tunu uhlí (při tehdejších exportních cenách rovnajících se 8 USD a více za tunu) ${ }^{44}$ a to v situaci, kdy polské uhlí bylo jedním z nejžádanějších artiklů na evropském trhu. V roce 1948 došlo k podepsání dohody, která zafixovala další polský vývoz na 6,5 milionu tun uhlí ročně za cenu 2,25 USD za tunu. Svých závazků týkajících se reparačního uhlí se Polsko zbavilo až v roce 1953 v návaznosti na ukončení dodávek německých válečných reparací Polsku a SSSR. Dle dobových odhadů bylo v období let 1946-1953 vyvezeno do SSSR cca 50 milionů tun uhlí za ceny rovnající se 5-8 \% jejich

41 KRANZ, J. - JAŁOWIECKI, B. - BARCZ, J. Miedzy pamięcią a odpowiedzialnościa. Rokowania w latach 1998-2000 w sprawie świadczeń za pracę przymusowa. Warszawa: „Prawo i Praktyka Gospodarcza“, 2004, s. 15: srovnej LUCAS, R. C. Bitter Legacy: Polish-American Relations in the Wake of World War II. University Press of Kentucky, 2010, s. 38 a násl.

42 Zbiór Dokumentów 1945, č. 2, s. 57.

43 Zbiór Dokumentów 1945, č. 2, s. 59.

44 LUCAS, c. d., s. 38 a násl., DOŁĘGA, J. - KULESA, Ł. - TARNOGÓRSKY, R. The USSR's Implementation of the Provisions of the Potsdam Agreement with Regard to Poland. In: GÓRALSKI, W. M. (ed.). Polish-German Relations and the Effects of the Second World War. Varšava: PISM, 2006, s. 160 a násl. 
tržní ceny, což nekrylo ani náklady dopravy. ${ }^{45}$ Celkové ztráty Polska z vývozu reparačního uhlí do SSSR za období 1946-1953 byly v roce 1956 odhadovány na 836 milionů USD v cenách uhlí na světovém trhu. ${ }^{46}$

Jakkoliv byly důsledky polsko-sovětské úmluvy o náhradě škod způsobených nacistickou okupací pro Polsko ekonomicky nevýhodné, můžeme konstatovat, že okamžikem podpisu úmluvy Polsko přistoupilo k ustanovením Postupimské dohody. ${ }^{47}$

\section{Prohlášení Rady ministrů z roku 1953}

Zatímco Polsko na londýnské konferenci zástupců ministrů zahraničních věcí v lednu 1947 vyjádřilo zájem na tom, aby v co nejkratším čase obdrželo rychlé a spravedlivé odškodnění, ${ }^{48}$ již o několik let později se svého nároku na válečné reparace ze strany Německa zcela vzdalo. Za účelem snížení finančního zatížení NDR byl dne 22. srpna 1953 zástupci NDR a Sovětského svazu podepsán Protokol o vynětí německých reparací a dalších opatřeních na zmírnění finančních a ekonomických závazků NDR souvisejících s důsledky války. ${ }^{49}$ Protokol stanovil, že v dohodě s polskou vládou dojde ke dni 1. ledna 1954 k ukončení účasti Polska na reparacích poskytovaných NDR ve formě dodávek zboží či jiné formě. Prohlášení zástupců obou států z téhož dne byly následně přeloženy do polštiny a zveřejněny. Následující den, tj. 23. srpna 1953, se Polsko jednostranným prohlášením Rady ministrů vzdalo nároků na náhradu škod vůči Německu, a to s účinností ke dni 1. ledna 1954: „S ohledem na skutečnost, že Německo již ve velké míře splnilo svoji povinnost odškodnění a protože zlepšení hospodářské situace Německa je v zájmu mírového rozvoje, vláda Polské lidové republiky rozhodla s účinností od 1. ledna 1954 o tom, že se vzdá vyplácení odškodnění určeného Polsku, aby tím přispěla k řešení německé otázky [...]. “50 Oproti protokolu ze dne 22. srpna 1953 podepsaného NDR a Sovětským svazem je zde podstatný terminologický rozdíl. Prohlášení Rady ministrů není adresováno NDR, ale Německu, a namísto válečných reparací používá termín odškodnění. Současně v ten samý den Polsko s úlevou akceptovalo rozhodnutí Sovětského svazu, které jej zbavovalo závazků ve věci reparačního uhlí, k nimž se Polsko zavázalo v roce 1945 . V polské argumentaci tato okolnost nepřímo potvrzuje tezi, že „,toto prohlášení nebylo iniciativou polské vlády, ale výsledkem nátlaku ze strany SSSR“. 51

Protože právní kontinuita Polska po roce 1989 s Polskou lidovou republikou je nepochybná, lze souhlasit s německou stranou, která považuje prohlášení Rady ministrů z roku 1953 za právně závazný akt a právní překážku současných nároků Polska. Analýza německého spolkového sněmu zde odkazuje na princip estoppel, který v mezinárodním právu veřejném brání státům účinně se dovolat námitky, která je v rozporu s předchozím prohlášením státu, a to za splnění dvou podmínek. První podmínkou je, aby takovéto prohlášení bylo jasné a jednoznačné a druhý stát byl oprávněn se za daných okolností na toto prohlá-

\footnotetext{
45 Poznámka č. 11, DOŁĘGA - KULESA - TARNOGÓRSKY, c. d., s. 181.

46 Poznámka č. 13, tamtéž.

47 Článek 3 úmluvy o náhradě škod způsobených nacistickou okupací ze dne 16. srpna 1945 výslovně stanoví, že úmluva nabývá účinnosti okamžikem podpisu.

48 Zbiór Dokumentów, 1947, č. 1-2, s. 45.

49 Zbiór Dokumentów, 1953, č. 9, s. 1830

50 Zbiór Dokumentów, 1953, č. 9, s. 1831

51 Analýza Sejmu, 2017, angl., s. 38.
} 
šení spolehnout, anebo se na toto prohlášení spolehl. Druhou podmínkou je, aby v důsledku uplatnění námitky vznikla druhému státu újma anebo aby namítající stát získal určitou výhodu nebo zisk. ${ }^{52} \mathrm{Z}$ toho vyplývá, že Polsko by mohlo uplatnit námitku neplatnosti prohlášení Rady ministrů z roku 1953 jen, pokud by vzdání se nároků na odškodnění/ válečné reparace bylo formulováno nejednoznačně anebo z dalších okolností by vyplynulo, že se NDR nemohla na takovéto prohlášení spolehnout. V této souvislosti je nicméně nezbytné zohlednit v té době existující principy aplikovatelné na jednostranné prohlášení států, které jsou způsobilé vyvolat právní povinnosti.

Věc však není ani z právního hlediska zdaleka tak jednoznačná, jak by se z německého stanoviska mohlo zdát. K tomu, aby jednostranné prohlášení státu bylo způsobilé založit práva a povinnosti, musí splňovat určité podmínky. Tyto existovaly v mezinárodním právu veřejném na úrovni principů a $\mathrm{v}$ pozdějším období byly rozpracovány v judikatuře Mezinárodního soudního dvora. Dnes výčet těchto principů obsahuje např́klad dokument OSN „Principy OSN aplikovatelné na jednostranné prohlášení států, jež jsou způsobilé vyvolat právní povinnosti“. Tato věc by si zasloužila bližší rozbor a zkoumání, nicméně můžeme zde vyjít z pracovní hypotézy, že většina těchto principů se na jednostranné prohlášení států aplikovala již počátkem 50. let minulého století. Kromě jiného z těchto principů vyplývá povinnost restriktivní interpretace v př́ípadě pochybností o obsahu určitého termínu v jednostranném prohlášení. ${ }^{53}$

Analýza Sejmu ze dne 6. záŕí 2017 shrnuje hlavní námitky, které na polské straně doposud zazněly k závaznosti jednostranného prohlášení Rady ministrů a k rozsahu, ve kterém se v něm Polsko vzdalo válečných reparací. I když Analýza Sejmu ze dne 6. září 2017 uvádí též argumenty pro neplatnost prohlášení ab initio (J. Sandorski, M. Muszynski), ${ }^{54}$ kontroverze vzbuzuje zejména rozsah, ve kterém se Polsko válečných reparací vzdalo. ${ }^{55}$ Spory souvisí například s důsledky výše zmiňovaných terminologických nejasností, které nerozlišují mezi válečnými reparacemi a škodami způsobenými civilistům v důsledku politiky okupačních orgánů anebo otázka, jestli se uvedené prohlášení vztahuje též na SRN, jež $\mathrm{v}$ té době neměla s Polskem navázané žádné diplomatické kontakty. ${ }^{56}$

52 Analýza německého spolkového sněmu, 2017, něm., s. 17.

53 Pricipy OSN aplikovatelné na jednostranné prohlášení států, jež jsou způsobilé vyvolat právní povinnosti, [online], 6. 11. 2017 [cit. 2017-11-06]. Dostupné na: http://legal.un.org/ilc/texts/instruments/english/ commentaries/9_9_2006.pdf.

54 Analýza Sejmu ze dne 6. záŕí 2017 k otázce neplatnosti odkazuje zejména na Jana Sandorski a Mariusze Muszynski. Podle Sandorskeho je prohlášení neplatné od samého počátku, protože bylo učiněno pod nátlakem SSSR, v důsledku toho nebyla splněna podmínka svobodné vưle jakožto podstatná náležitost právně relevantního jednání, viz SANDORSKI, J. Zrzeczenie się w 1953 r. przez Polskę reparacji wobec Niemiec w świetle prawa międzynarodowego. In: GÓRALSKI, W. M. Problem reparacji, odszkodowań i świadczeń w stosunkach polsko - niemieckich 1944-2004. Vol. I „Studia“. Warszaw: PISM, 2004. Podle Muszynskeho prohlášení nesplňuje náležitosti, které pro závaznost jednostranného prohlášení požaduje mezinárodní právo veřejné, viz MUSZYŃSKI, M. Prawnomiędzynarodowe podstawy niemieckich zobowiązań reparacyjnych na rzecz zwycięskiej koalicji ze szczególnym uwzględnieniem Polski. In: GÓRALSKI, Problem reparacji.

55 Stanovisko, že prohlášení z roku 1953 je sice právně závazné, nicméně sporný je rozsah, ve kterém došlo k vzdání se odškodnění ze strany Polska, zastávají např. Władysław Czapliński, Jerzy Kranz, Jerzy Menkes, Robert Grzeszczak, Krzysztof Indecki, viz Analýza Sejmu, 2017, angl., s. 25.

56 Analýza Sejmu ze dne 6. zář́ 2017 v této souvislosti opakovaně zdůrazňuje polské stanovisko, podle kterého od válečných reparací je potřeba odlišit ztráty v souvislosti s německou okupací, jež v Polsku tvořily 
Analýza německého spolkového sněmu argumentuje zejména tím, že Polsko ve svém prohlášení nečinilo rozdíl mezi př́mými válečnými škodami a škodami z nacistické persekuce. ${ }^{57}$ Naopak polské stanovisko prezentované např́klad Jerzym Kranzem, polským právníkem, který zastupoval Polsko v letech 1998 až 2000 na jednáních o odškodnění obětí nucených prací, trvá na odlišení válečných reparací od dalších nároků konkrétních fyzických a právnických osob: „Podle Polska, vzdání se válečných reparací nezahrnovalo nároky polských fyzických a právnických osob na náhradu škod, které utrpěly v souvislosti s nacistickou persekucí, včetně nucených prací či v důsledku deportace. “58 Obdobně Jan Barcz v souvislosti s polskými kompenzačními nároky vůči Německu konstatuje: „Po pravdě v Polsku nikdo nezpochybňuje fakt, že otázka válečných reparací ze strany Německa byla již uzavřena, avšak ne všechny nároky byly kvalifikované jako reparace. Zejména zde byla shledána potřeba uspokojit nároky bývalých vězňů koncentračních táborů a obětí nucených prací v Německu. “59

V otázce, jestli se polské prohlášení vztahuje pouze na NDR anebo též na SRN, německý spolkový sněm vychází z čl. 2 hlavy 3 Postupimské dohody a dále z textu sovětského prohlášení z roku 1953: „Nakonec sovětská vláda prohlásila, že ,Německo“ bylo výslovně prosté placení poválečného státního dluhu Sovětskému svazu. Vzhledem k tomu, že sovětská vláda v předchozím textu protokolu uvedla pravidla týkající se vzdání se odškodnění „Německé demokratické republiky“, a také vzhledem k preambuli protokolu a osvobození obou částí „Německa“"v odkazech, je zřejmé, že Německo by mělo být upřednostněno jako celek."60 Opačný názor na polské straně zastává např́klad A. Klafkowski. ${ }^{61}$

Z výše nastíněných nejasností je zřejmé, že prohlášení Rady ministrů z roku 1953 je zatíženo celou řadou interpretačních problémů, které sice nutně nemusí způsobovat jeho neplatnost v mezinárodním právu veřejném, nicméně vytvářejí interpretační prostor pro další politická jednání v otázce polských nároků na odškodnění ze strany Německa.

\section{Polsko-německé smíření počátku 70. let}

Dne 7. prosince 1970 německý spolkový kancléř Willy Brandt navštívil Varšavu za účelem podpisu smlouvy o normalizaci poměrů obou států. Jednalo se o významný okamžik polsko-německých bilaterálních vztahů, který je považovaný za počátek obratu v západoněmecké zahraniční politice směrující vůči východoevropským zemím a první diplomatický krok vedoucí k prolomení Železné opony. V rámci své návštěvy se německý spolkový kancléř zúčastnil vzdání pocty židovským obětem nucených transportů do vyhlazovacích táborů u památníku hrdinů Varšavského ghetta. Vystoupil z auta, přiblížil se k pomníku a neočekávaně klesl na kolena, kde v tichu setrval asi minutu. Toto gesto, o jehož spontán-

\footnotetext{
90 \% veškerých ztrát, které Polsko utrpělo v souvislosti s druhou světovou válkou. Analýza Sejmu, 2017, (angl.), s. 38.

57 Analýza německého spolkového sněmu, 2017, něm., s. 17.

58 KRANZ - JAŁOWIECKI - BARCZ, c. d., s. 15.

59 BARCZ, J. The legal bases of Poland s relations with United Germany. In: GÓRALSKI, W. M. Poland-Germany 1945-2007: From Confrontation to Cooperation and Partnership in Europe. Varšava: PISM, 2007, s. 115 a násl.

60 Analýza německého spolkového sněmu, 2017, něm., s. 18.

61 Analýza Sejmu, 2017, angl., s. 25.
} 
nosti se dlouho spekulovalo, vzbudilo silný pozitivní ohlas. ${ }^{62}$ Valentin Rauer mluví o tomto okamžiku jako o „,výjimečné události“, jež „,znamenala počátek nové etapy na trajektorii německé identity a paměti“, a prvním veřejném symbolu uznání německé viny, po kterém v Německu nenásledovaly okamžité obecné defenzivní reakce. ${ }^{63}$ Tímto gestem Německo potvrdilo svojí morální odpovědnost za válečné zločiny způsobené Polákům.

Ve smlouvě o normalizaci poměrů ze dne 7. prosince $1970^{64}$ SRN a Polsko prohlásily, že si přejí rozvíjet vzájemné dobré vztahy v budoucnosti a posílit základy mírového soužití a bezpečnosti v Evropě. Za tímto účelem smlouva potvrdila západní hranice Polska vymezené Postupimskou dohodou. Smlouva o normalizaci poměrů neobsahovala žádné ustanovení týkající se válečných reparací. Nicméně v důsledku jejího uzavření se polským státním příslušníkům otevřely dveře k západoněmeckým financím určeným pro oběti nacistických persekucí, které SRN uvolňovala v 70. a 80. letech.

Dne 16. listopadu 1972 byla v ženevském sídle Mezinárodního červeného kříže zástupci obou států podepsána úmluva o pomoci obětem pseudolékařských experimentů, ${ }^{65}$ na jejímž základě Polsko obdrželo od Mezinárodního Červeného křriže (ze západoněmeckých zdrojů) jednorázovou platbu ve výši 100 milionů německých marek určenou pro oběti nacistických lékařských experimentů primárně nežidovského původu. V článku 3 Úmluvy se strany dohodly, že uvedená částka bude představovat konečné vypořádání polských nároků ve věci pseudolékařských experimentů v nacistických koncentračních táborech (čl. 3 odst. 1). Polští státní př́íslušníci tímto dále pozbyli oprávnění uplatňovat individuální nároky v této věci vưči Německu (čl. 3 odst. 2), protože povinnost vyplatit odškodnění obětem lékařských experimentů tímto přešla na Polsko (čl. 3 odst. 3). Zde je potřeba zmínit, že ještě před podpisem úmluvy došlo ze strany SRN k odškodnění 1357 osob s polským státním občanstvím, jež v důsledku nacistických lékařských experimentů utrpěly újmu na zdraví. ${ }^{66}$ Podle čl. 4 Úmluvy měla být platba vyplacena ve dvou splátkách, první splátka měsíc po podpisu úmluvy, druhá splátka 1. listopadu 1973. Do konce roku 1974 bylo přijato 10518 žádostí, z nichž byla náhrada přiznána 3524 osobám. ${ }^{67} \mathrm{~V}$ roce $1976 \mathrm{z}$ této platby zůstala částka ve výši 40,17 milionů německých marek, která byla částečně přrerozdělena

62 V knížce vzpomínek Erinnerungen: Mit den Notizen zum Fall G(1989) Willy Brandt popisuje motivy svého činu: „Neměl jsem žádný plán, ale ze zámku Wilanow, kde jsem byl ubytován, jsem odešel s pocitem, že bych měl nějak vyjádřit výjimečnost uctění památky obětí u památníku hrdinů Varšavského ghetta. Nad propastí německé historie pod tíhou vzpomínek na miliony zavražděných, udělal jsem to, co lidé dělají, když slova nestačí."BRANDT, W. Erinnerungen: Mit den Notizen zum Fall G. Hamburk, 1989; srov. RENNER, J. Germany - Poland: The Ritualization of Apology. In: DAASE, Ch. - ENGERT, S. - HORELT, M. A. - RENNER, J. - STRASSNER, R. (eds.). Apology and Reconciliation in International Relations: The Importance of Being Sorry (Routledge Advances in International Relations and Global Politics). 1st Edition. Routledge, 2015, s. 51-70; RAUER, V. Symbols in action: Willy Brandt's kneefall at the Warsaw Memorial. In: ALEXANDER, J. - GIESEN, B. - MAST, J. (eds.). Social Performance: Symbolic Action, Cultural Pragmatics, and Ritual. Cambridge: Cambridge University Press, 2006, s. 257-282.

63 RAUER, c. d., s. 257-282.

64 The Treaty of Warsaw, 7th December 1970, United States-Department of State. Documents on Germany 1944-1985. Washington: Department of State, [s.d.]. 1421 p. (Department of State Publication 9446). p. 1125-1127, [online], 6. 11. 2017 [cit. 2017-11-06]. Dostupné na: https://www.cvce.eu/content/publication /1999/1/1/7f3363b0-2705-472a-b535-c42bd229f9e2/publishable_en.pdf.

65 Dokument č. 96, DĘBSKI - GÓRALSKI, c. d., s. 1 a násl.

66 Dokument č. 97, tamtéž.

67 Dokument č. 104, tamtéž. 
mezi oprávněné osoby, kterým doposud nebyla náhrada přiznána, a částečně byla tato částka vynaložena na nákup specializovaných zdravotnických př́strojů pro nemocnice a na výstavbu sanatoria pro veterány a bývalé vězně koncentračních táborů. ${ }^{68}$ Analýza polského Sejmu ze dne 6. září 2017 upozorňuje, že se nejednalo o náhradu škody stricto sensu, ale dle výslovného znění úmluvy o humanitární pomoc. Tato formulace byla SRN zvolena s ohledem na dlouhodobé stanovisko Německa odmítajícího smluvně uznat svoji právní odpovědnost vůči Polsku za škody zpo̊sobené obětem nacistických persekucí.

Z dokumentů gen. štábu polské armády z konce roku 1972 vyplývá, že Polsko považovalo výše citovanou úmluvu za první krok k odškodnění civilních obětí nacistických persekucí a připravovalo strategii dalších jednání o odškodnění. Podle této strategie mělo následovat odškodnění bývalých vězňů a obětí masové exterminace v koncentračních táborech a dále nároky invalidních obětí. Po těchto skupinách měly následovat další skupiny osob poškozených nacistickými persekucemi. ${ }^{69}$ Př́ípravné práce probíhaly zejména na půdě Komise pro otázku německých kompenzací (1970-1974) a hlavní Komise pro studium nacistických zločinů v Polsku. ${ }^{70}$ Dne 9 . ř́jna 1975 došlo mezi oběma státy k podepsání úmluvy o penzích pro osoby v důchodcovském věku a invalidy, nicméně tato dohoda se vztahovala na nároky z pojištění osob, které byly před rokem 1945 pojištěnci německých pojištoven. ${ }^{71}$

V dalším období Polsko nadále vynakládalo úsilí k projednání dalších odškodňovacích nároků vůči SRN. Př́kladem lze zmínit nótu polského ministerstva zahraničních věcí adresovanou ministerstvu zahraničních věcí SRN z prosince 1986, ve které Polsko žádalo, aby SRN byla v otázce náhrady škod způsobených žijícím obětím druhé světové války iniciativnější. ${ }^{72}$ Rozdělení světa do dvou nepřátelských bloků znemožňovalo najít vhodné řešení této problematiky, avšak sblížení SRN a Polska na počátku 70. let přineslo logicky oživení iniciativ směřujících k odškodnění polských obětí nacistických persekucí.

\section{Sjednocení Německa}

U prŕiležitosti 50. výročí uctění památky varšavského povstání v roce 1994 tehdejší německý prezident Roman Herzog pronesl tato slova: „Během posledních 40 let prošly evropské dějiny dramatickými změnami. Národy se začaly sjednocovat ve sjednocené Evropě. Nikdo se nemusí vzdát své národní identity, nikdo se nemusí zrríct své kultury a dějin. Musíme se pouze zříct nepřátelství a nenávisti a malé části našeho národního sobectví. Západně od Železné opony tato myšlenka dokázala zázraky. Dnes je tato cesta otevřena též Polákům, kteří byli odjakživa součástí Evropy a kteří postrádali Evropany dlouhých čtyřicet let. V tomto novém rámci mohou Poláci a Němci společně žít podobně jako je tomu již dlouho mezi Francouzi a Němci. V každém př́padě bude Německo vždy podporovat úsilí Poláků o členství v Evropské unii a NATO. Nemůžeme udělat nic lepšího pro naše děti a vnoučata. Nicméně dnes se skláním před bojovníky Varšavského povstání a před všemi válečnými obětmi polské státní příslušnosti. Prosím o odpuštění za to, co jim bylo způso-

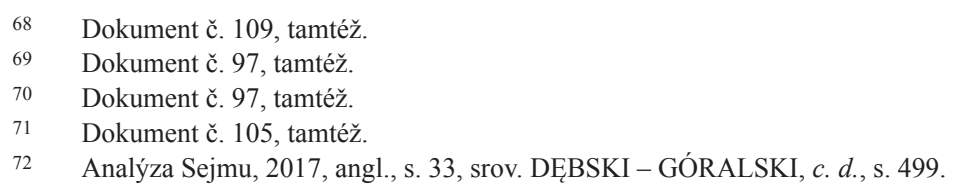


beno ze strany Němců. “73 Tato pečlivě volená slova omluvy německého prezidenta naznačovala směr, jakým se polsko-německé vzájemné vztahy mohly v dalších letech vydat.

A skutečně, zatímco 70. léta charakterizuje politika smíření obou zemí, pád komunistických režimů v zemích střední a východní Evropy přinesl důležitý impulz směrem $\mathrm{k}$ institucionalizaci této politiky. Jelikož počátky politické a ekonomické transformace Polska probíhaly paralelně s procesem německého sjednocení, vytvořil se ve vzájemných vztazích obou států prostor k uzavření sporných otázek minulosti a k navázání silného polsko-německého partnerství v sjednocující se Evropě. Vývoj ukázal, že se to podařilo jen v omezené míře. Jan Barcz ve své práci o právním základu polsko-německých vztahů po roce 1990 identifikoval dva klíčové problémy, které bylo potřeba v tomto okamžiku s konečnou platností vyřešit. Prvním bylo uznání polsko-německých hranic a s tím související majetkoprávní otázky. Druhým byla otázka válečných reparací a odškodnění za nacistickou okupaci. ${ }^{74}$

Z protokolu Pařížské konference ze dne 17. července 1990 vyplývá, že SRN možnost uzavření pozdější mírové smlouvy vyloučila. ${ }^{75}$ Namísto ní byla $\mathrm{v}$ předvečer německého sjednocení USA, Velkou Británií, Francií, SSSR, NDR a NSR uzavřena Smlouva o konečném řešení ve vztahu k Německu (Smlouva 2 plus 4), ${ }^{76}$ jež tuto mírovou smlouvu fakticky nahradila. Zatímco otázka polsko-německé hranice byla v této smlouvě uzavřena s konečnou platností, majetkoprávní otázky související s druhou světovou válkou a jejími důsledky v ní nejsou výslovně upraveny.

V průběhu pařížských jednání o obsahu Smlouvy 2 plus 4, jichž se Polsko účastnilo, nevznášelo žádné vlastní nároky ani neprotestovalo proti tomu, že uzavřením smlouvy budou tyto nároky do budoucna oslabeny. Naopak poté, co byla Smlouva 2 plus 4 uzavřena, v listopadu 1990, Polsko bez výhrad přistoupilo k Pařížské chartě pro novou Evropu. Německá strana z těchto okolností dovozuje tichý souhlas Polska s konečným uzavřením otázky válečných reparací a odškodnění: „Na základě tohoto chování lze konstatovat, že již samotné Polsko bylo toho názoru, že již nemůže požadovat odškodnění. “77 Opačný názor polské strany je zřejmý z Analýzy Sejmu ze dne 6. záŕí 2017. Analýza upozorňuje, že Smlouva 2 plus 4 otázku válečných reparací neupravila na naléhání německého kancléře Helmuta Kohla, a proto tato otázka zůstala do budoucna otevřena: ,je třeba připomenout, že podle čl. 35 Vídeňské úmluvy o smluvním právu z 23. května 1969 ,třetímu státu vznikne závazek z ustanovení smlouvy, jestliže strany této smlouvy mají v úmyslu tímto ustanovením vytvořit závazek a jestliže třetí stát tento závazek výslovně přijme písemnou formou‘. Proto, aby Smlouva dva plus čtyři mohla vést na straně polského státu ke ztrátě práva na náhradu škody, musely by strany Smlouvy uvést, že takový záměr skutečně exis-

73 Projev Romana Herzoga ve Varšavě dne 1. srpna 1994, [online], 6. 11.2017 [cit. 2017-11-06]. Dostupné na: http://www.bundespraesident.de/SharedDocs/Reden/DE/Roman-Herzog/Reden/1994/08/19940801_Rede. html.

74 BARCZ, J. The legal bases of Poland s relations with United Germany. In: GÓRALSKI, W. M. Poland-Germany 1945-2007: From Confrontation to Cooperation and Partnership in Europe. Varšava: PISM, 2007, s. 115 a násl.

75 BARCZ, J. Udziat Polski w konferencji ,2+4“. Aspekty prawne i proceduralne. Varšava: PISM 1994, s. 166 a násl.

76 Smlouva 2 plus 4, [online], 6. 11. 2017 [cit. 2017-11-06]. Dostupné na: https://reaties.un.org/doc/Publication /UNTS/Volume\%201696/volume-1696-I-29226-English.pdf.

77 Analýza německého spolkového sněmu, 2017, něm., s. 21. 
toval a Polsko by muselo výslovně přijmout tento závazek.“ Bohužel tato argumentace se již nevypořádá s možnou námitkou, že uvedené pravidlo v čl. 35 Vídeňské úmluvy existovalo v nekodifikované formě již před podpisem Vídeňské úmluvy v podobě mezinárodního obyčeje, který je třeba aplikovat na přistoupení Polska k Postupimské dohodě. Uzavřením bilaterálních polsko-sovětských úmluv ze dne 16. srpna 1945 Polsko projevilo souhlas s těmi ustanoveními Postupimské úmluvy, které jej ve věci reparačních nároků odkazovaly na SSSR (a platby ze sovětské okupační zóny pozdější NDR). Ve shodě s německým stanoviskem interpretuje důsledky uzavření Smlouvy 2 plus 4 na nárok Polska na válečné reparace též část polské doktríny mezinárodního práva veřejného. ${ }^{78} \mathrm{Zde}$ lze zmínit např́íklad slova Jerzy Kranze: „Na druhou stranu tato smlouva nevznikla ve vakuu a vyjadřuje vůli stran (jež nebyla nikdy zpochybněna). Tato kapitola je proto uzavřena - což nepřekáželo tomu, aby některé otázky byly upraveny ve dvoustranných smlouvách a politických dohodách s Německem.“79

Dne 17. června 1991 podepsalo Německo a Polsko bilaterální polsko-německou smlouvu o dobrém sousedství a prátelské spolupráci. ${ }^{80}$ Tato smlouva stanovila rámec další polsko-německé spolupráce v Evropě, kde sjednocené Německo opět zaujalo klíčovou ekonomickou a politickou pozici. Ve smlouvě Německo vyjádřilo podporu integračním ambicím Polska směřujícím k jeho začlenění do Evropské unie a NATO, avšak byla zde upravena i celá řada dalších otázek.

Dne 16. října 1991 oba státy uzavřely formou výměny nót úmluvu o vytvoření Nadace polsko-německého smíření. ${ }^{81} \mathrm{Na}$ základě této úmluvy Německo uvolnilo Nadaci polsko-německého smíření jednorázovou finanční dotaci 500 milionů německých marek. Účelově byly tyto finance vázány na pomoc obětem nacistických persekucí, které v důsledku nacistické okupace utrpěly závažnou zdravotní újmu a nacházely se ve složité finanční situaci. Z prohlášení německé strany vyplývalo, že další financování této nadace bude zajištěno s podporou německých společností. ${ }^{82}$ Z Analýzy polského Sejmu ze dne 6. záŕí 2017 vyplývá, že v rozmezí let 1992 až 2004 Nadace vyplatila celkovou částku 731843600 polských zlotých celkovému počtu 1060689 osob, což v přepočtu znamená 689,97 zlotých na osobu. Úmluva blíže nespecifikovala, jaká opatření nacistické politiky odškodňuje (např. nezákonné omezení svobody v důsledku uvěznění, nucené práce apod.), ani nepoužívala výraz reparace nebo odškodnění, ale opět mluvila o této částce pouze jako o pomoci nebo humanitárním gestu. Akceptační nóta polské strany nicméně potvrdila, že Polsko tímto okamžikem považuje otázky upravené touto úmluvou za uzavřené s konečnou platností, a Polsko prohlásilo, že nebude dále přijímat žádné nároky polských občanů v souvislosti s nacistickou okupací, přičemž „obě vlády souhlasí, že uvedené nebude omezovat nároky státních př́íslušníků obou států."83 Mohli bychom tedy konstatovat, že tímto okamžikem

78 CZAPLIŃSKI, W. Regulacja pokojowa z Niemcami po II wojnie światowej. Państwo i Prawo, 1990, č. 2 , s. 45. RAUSCHNING, D. Beendigung der Nachkriegszeit mit dem Vertrag über abschliessende Regelung im bezug auf Deutschland. Deutsche Verwaltungsblätter, 1990, s. 1280. KRANZ, J. - BACHMANN, K. Die Nulloption scheint ein Faktum zu sein: Bemerkungen zum deutsch-polnischen Reparationsstreit. Reports and Analyses 11/04. Warschau: Centrum Stosunkow Miedzynarodowych (CSM), 2004.

80 Dz.U. 1992 nr.14 poz. 56.

81 Dokument č. 127, DĘBSKI - GÓRALSKI, c. d., s. 537.

82 KRANZ - JAŁOWIECKI - BARCZ, $c$. d., s. 2.

83 Dokument č. 127, DĘBSKI - GÓRALSKI, c. d., s. 538. 
angažmá polského státu ve věci odškodnění fyzických a právnických osob v souvislosti s nacistickou okupací končí a že nadále budou moct oprávněné osoby polské státní příslušnosti uplatňovat své nároky pouze v rámci soudních ř́zení podle německého práva.

\section{Jednání o odškodnění obětí nucených prací}

A přece, druhá polovina 90. let znovu otevřela otázku odškodnění polských obětí nacistických persekucí, a to v souvislosti s vývojem nároků na odškodnění obětí nacistických persekucí ve Spojených státech. V první polovině roku 1998 byly před americkými soudy podány první hromadné žaloby proti německým společnostem těžícím v době druhé světové války z nucené práce. ${ }^{84} \mathrm{~V}$ této době se otázka odškodnění polských obětí nucené práce dostala do centra pozornosti polské vlády. Podle Jerzyho Kranze na vládní návštěvě Německa, která se uskutečnila počátkem července 1998, předseda vlády Jerzy Buzek informoval německou stranu o tom, že německá právní úprava odškodnění obětí nucené práce zachází s polskými státními příslušníky diskriminačně, což na německé straně nevyvolalo větší reakci. ${ }^{85} \mathrm{~K}$ další korespondenci obou vlád došlo v prosinci téhož roku poté, co SRN čelila silné medializaci a veřejnému tlaku ve Spojených státech, kde v té době bylo proti německým společnostem podáno již více než padesát hromadných žalob. Dne 22. prosince 1998 Wieslaw Walendziak, vedoucí kanceláře předsedy rady ministrů Polska, odeslal dopis Bodo Hombachovi, vedoucímu kanceláře ministerstva pro zvláštní potřeby, v němž polská strana požadovala, aby při projednávání dodatečných nároků směřujících k odškodnění obětí nucené práce nebyli polští státní příslušníci diskriminováni a byla jim vyplacena spravedlivá náhrada. Německá strana v odpovědi odmítla existenci jednání se Spojenými státy, avšak přiznala, že jedná s německými společnostmi o vytvoření odškodňovacího fondu. ${ }^{86} \mathrm{~V}$ této době se polská vláda spojila s americkými právníky a v lednu 1999 byla před americkými soudy podána hromadná žaloba na německé společnosti ze strany polských obětí. ${ }^{87}$ To byl začátek polské účasti na multilaterálních jednáních o odškodnění obětí nucených prací, jež skončila dne 17. července 2000 v Berlíně přijetím dvou z balíčku dokumentů, který sestával ze společného stanoviska, německo-americké úmluvy o vytvoření nadace Připomínka, odpovědnost a budoucnost a německého federálního zákona ze dne 12. srpna 2000, na jehož základě nadace vznikla. ${ }^{88}$ Ze zprávy nadace z roku 2017 vyplývá, že z celkové sumy odškodnění, jež byla stanovena na 10 miliard německých marek (5,1 miliard euro) bylo odškodněno 1,66 milionu žadatelů z 89 zemí. Polským žadatelům (484 025) z toho připadlo 974 milionů euro, což bylo vůbec poprvé, co Polsku v komparativním srovnání bylo přiděleno adekvátní odškodnění z celkové částky 4,34 miliardy euro,

84 BAZYLER, M. J. - FITZGERALD, A. L. Trading with the Enemy: Holocaust Restitution, the United States Government, and American Industry, 28 BROOK. J. INT'L L., [online], 6. 11. 2017 [cit. $2017-$ 11-06]. Dostupné na: http://brooklynworks.brooklaw.edu/cgi/viewcontent.cgi?article=1349\&context=bjil.

85 KRANZ - JAŁOWIECKI - BARCZ, c. d., s. 3.

86 Dokumenty č. 131 a 132, DĘBSKI - GÓRALSKI, $c . d$.

87 KRANZ - JAŁOWIECKI - BARCZ, c. d., s. 3.

88 SAATHOFF, G. - GERLANT, U. - MIETH, F. - WÜHLER, N. (eds.). The German Compensation Program and Forced Labor: Practice and Experiences. Berlin: Stiftung Erinnerung, Verantwortung und Zukunft, 2017, [online], 6. 11. 2017 [cit. 2017-11-06]. Dostupné na: https://www.stiftung-evz.de/fileadmin /user_upload/EVZ_Uploads/Publikationen/Englisch/EVZ_Compensation_Program.pdf. 
jež byla rozdělena mezi oběti nucené práce v letech 2000-2007. ${ }^{89}$ Okamžikem podpisu německo-americké úmluvy se v právní rovině uzavřela nejen otázka odškodnění obětí nucených prací, ale taky otázka odškodnění obětí druhé světové války vůbec. V článku 3 úmluvy se Spojené státy zavázaly dále nevznášet vůči SRN žádné odškodňovací nároky a do budoucna podniknout vhodná opatření k tomu, aby zabránily jakémukoliv zpochybňování státní suverenity SRN v případě jakýchkoliv dalších nároků směřujících vưči SRN na odškodnění důsledků národního socialismu a druhé světové války. Tímto okamžikem polské naděje na americkou diplomatickou podporu dalších nároků na odškodnění ze strany SRN v souvislosti s druhou světovou válkou výrazně oslabily.

\section{Závěr}

Závěrem připomeňme klíčové okamžiky, které vedly k postupnému právnímu uzavření otázky polských nároků na odškodnění válečných škod a souvisejících finančních nároků polských státních příslušníků v odpovědnosti Německa ve druhé polovině 20. století. Podle ustanovení Postupimské dohody bylo Polsko v otázce válečných reparací odkázané na dohodu se SSSR. Uzavřením dohody o hranicích a uhelné dohody projevilo souhlas řídit se sovětským režimem válečných reparací, byt' byl pro Polsko značně nevýhodný. S ohledem na právní kontinuitu Polské republiky po roce 1989 s Polskou lidovou republikou v letech 1952-1989 představuje jednostranné prohlášení Rady ministrů z roku 1953 závazný právní akt, kterým je Polská republika povinna se řídit i v současnosti. Ve shodě s částí polské doktríny se nicméně domnívám, že ustanovení tohoto prohlášení je potřeba interpretovat restriktivně a že jej nelze vztáhnout na nároky fyzických a právnických osob polské státní příslušnosti na náhradu škod způsobených v souvislosti s nacistickou okupací Polska. Tvrdím nicméně, že k uzavření otázky válečných reparací v právní rovině došlo s konečnou platností na počátku 90. let v souvislosti s přijetím Smlouvy 2 plus 4 , jež neexistující mírovou smlouvu nahradila, a navazujícími bilaterálními polsko-německými smlouvami, jejichž účelem bylo uzavřít sporné otázky minulosti a umožnit budoucí německo-polskou spolupráci ve sjednocující se Evropě. V této době Polsko mělo příležitost aktivně namítat neplatnost jednostranného prohlášení Rady ministrů z roku 1953. K takovéto aktivitě Polska nicméně nedošlo. Naopak Polsko podepsalo smlouvy stanovící rámec budoucí polsko-německé spolupráce, v jejichž důsledku získalo klíčovou podporu Německa při jednáních o vstupu do Evropské unie a NATO.

Ve věci nároků polských státních příslušníků na náhradu škod způsobených v souvislosti s okupací Polska nacistickým Německem je potřeba odlišit dva režimy: režim mezinárodněprávní ochrany, ve kterém nároky polských státních příslušníků na náhradu škod zpo̊sobených druhým státem zastupuje Polsko a režim vnitrostátní právní ochrany, ve kterém poškozené osoby uplatňují své nároky cestou soudního řízení vedeného soudy a na základě právních předpisů států, který škodu způsobil. Zatímco druhá možnost zůstala polským státním příslušníkům otevřena i po uzavření bilaterální polsko-německé úmluvy o vytvoření Nadace polsko-německého smíření (1991), první možnost se v právní rovině okamžikem její ratifikace uzavřela.

89 KRANZ - JAŁOWIECKI - BARCZ, c. d., s. 4, srov. SAATHOFF - GERLANT - MIETH - WÜHLER, c. d., s. 23 . 
Od roviny právní je nicméně potřeba odlišit rovinu mezinárodní politiky. V této rovině došlo k znovuotevření otázky odškodnění civilních obětí nacistického režimu ve druhé polovině 90. let. Stalo se tak v důsledku soustředěného tlaku Spojených států amerických. V tomto období se na základě hodnotové argumentace lidskými právy opět otevřela otázka odškodnění obětí holokaustu. Pro aktuální nároky Polska vůči Německu je nicméně podstatná německo-americká úmluva o vytvoření nadace Připomínka, odpovědnost a budoucnost z července 2000. Tato úmluva představuje definitivní právní tečku za kapitolou odškodnění obětí nacistických persekucí ze strany Německa. Od okamžiku její ratifikace jsou Spojené státy americké vázány povinností nevznášet další nároky vůči SRN a bránit dalším iniciativám v této oblasti. Protože v současnosti je americká diplomatická podpora klíčovým faktorem úspěchu jednání o náhradě škod z doby druhé světové války, můžeme tuto část uzavřít s tím, že polské šance na získání dalšího odškodnění ze strany SRN nejsou vysoké. 